\title{
Internet Censorship in Arab Countries: Religious and Moral Aspects
}

\author{
Alisa Shishkina * and Leonid Issaev \\ Laboratory for Monitoring of Sociopolitical Destabilization Risks, National Research University Higher School \\ of Economics, Moscow 101000, Russia; lisaev@hse.ru \\ * Correspondence: ashishkina@hse.ru; Tel.: +7-916-064-1087
}

Received: 27 October 2018; Accepted: 11 November 2018; Published: 14 November 2018

\begin{abstract}
Internet censorship remains one of the most common methods of state control over the media. Reasons for filtering cyberspace include ensuring the security of the current regime, attempts to limit all kinds of opposition movements, and the protection of the religious and moral norms of society. In Arab countries, where religion plays a major role in the sociopolitical sphere, the latter is particularly important. Since, in Islamic law, there is no direct reference to censorship in practice, governments cause many resources to be filtered under various pretexts. At the same time, as the example of Egypt during the Arab spring shows, moral and religious reasons for filtering the Internet have more grounds than, say, the persecution of opposition leaders.
\end{abstract}

Keywords: Internet censorship; Islam; Arab spring; Qur'an; morality

\section{Introduction}

Due to the spread of the Internet in the region of the Middle East and North Africa, its impact on the processes occurring in Arab societies, and their consequences, have been reflected in many papers. In addition to data from statistical bureaus (e.g., Arab IP Centre 2013; World Bank 2012; Internet World Stats 2015), studies have been conducted by Altermann (1998), Aday et al. (2012), Armando (2013), and Langman and Douglas (2002). The important role that social networks played in the political space of the Arab countries during the last decade, especially at the time of the events of and after the Arab Spring, is discussed by many authors, including Moore (2011), Middle East Voices (2012), Karolak (2011), Arab Social Media Report (2011), Diamond (2012), Howard and Parks (2012), Newsom and Lara (2012), Dainotti et al. (2011), Szajkowski (2011), Lifintseva et al. (2015) and others. At the same time, other papers, for example, those of Swigger (2013) and Langman and Douglas (2002), refer to the study of the transformations that Arab societies are undergoing as the Internet expands-in particular, the growth of online activism by women and the impact of virtual environments on the democratic attitudes of citizens.

According to Deibert (2009), the motivations for Internet filtering practices range widely, from concerns over national security, cultural sensitivities, and protection of social values, to rent-seeking and the protection of economic monopolies. Many reports from international organizations and research centers (Arab Social Media Report 2011; Freedom House 2011, 2015; Human Rights Watch 1999; Reporters Without Borders 2016; The Emirates Center for Strategic Studies and Research 2006; Bureau of Democracy, Human Rights, and Labor 2016; Freedom on the Net 2018; etc.), as well as individual researchers (e.g., Warf and Grimes 1997; Khazen 1999; Houissa 2000; Abdulla 2007; Dainotti et al. 2011; Shishkina and Issaev 2015) have been devoted to the study of forms of control in the media space (both the so-called traditional media and Internet resources) of Arab countries, as well as the description of techniques, methods, and the prevalence of Internet censorship. 
At the same time, most authors emphasize that, within Arab countries, there are serious discrepancies between the right to free expression of thoughts and restrictions in virtual spaces.

Discussions on the development of institutions of civil society, along with the spread of new information technologies, often address issues such as the involvement of young people in these processes. Howard (2010) states that Arab youth have triggered online activism and online participation, challenging all practices of censorship. Al-Kandari and Hasanen (2012) conclude that political engagement is positively predicted by the use of Facebook, Twitter, and blogs, as well as the use of the Internet to seek information. Other researchers point out that Internet tools and social media networks, especially in Tunisia and Egypt, encouraged relatively less-violent forms of protest (e.g., Stepanova 2011; Allagui and Kuebler 2011; Tufekci and Wilson 2012). They conclude that a new genre of revolution appeared, whose distinguishing feature is its organization via networks and, particularly, by digital social networks, which played an important informational and organizational role.

According to Jansen (2010), digital activists are organized in social organizations that actively express or engage online, for development of the movement and to promote social change. Lerner (2010) is based on the idea that the Internet is used to inspire sympathetic individuals to real-world political action, examplified by the blogging of the Muslim Brotherhood in Egypt.

Hofheinz (2005) states that the Arab segment of the Internet is characterized by two features: first, religion plays a more important role that anywhere else in the world and, second, users in Arab countries are particularly eager to engage in discussion-not least of all, politics, religion, and sex. Here, it should also be mentioned the connection between religion and morality in the region under analysis. Thus, Inglehart and Baker (2000) note the persistence of traditional values in Arab countries, despite the economic development and subsequent systematic changes in basic values; and Ayubi refers to the traditional concern in Islam for the collective enforcement of morals (Ayubi 2003).

However, as a rule, little attention is paid to sociocultural, religious and moral reasons, and aspects of extensive censorship of media resources in the Arab countries. Abdulla (2007) considers different political and cultural ideologies in the Arab world, coming, nevertheless, to the conclusion that Arabs experienced, maybe for the first time in their long history, the flow of information without boundaries, and communication with each other without censorship, through an instant communication channel.

Particular attention is paid to Egypt's cyberspace by researchers, since this country was one the most developed countries of the region in terms of Internet coverage and technologies and, moreover, along with Tunisia, it was the locomotive of the Arab Spring processes, experiencing the most vivid trends and features of that new type of protest movement. Thus, Calingaert (2010) underlines that Egypt encourages expanded Internet access and permits broad space for free expression online, despite heavy restrictions on traditional media. Herrera (2012) points out that Egyptian youth had been learning citizenship during the Arab Spring, forming a generational consciousness, and actively engaging in politics using new media. Egypt, along with some other Arab countries, is considered a moderate cyberspace censor which, to some extent, may be explained by the state's orientation towards the West (Anderson 2003), as well as governments' eagerness to attract foreign investors and stimulate tourism (Warf 2011). Nevertheless, censorship prevalence remains widespread in this Arab country.

However, as a rule, little light is shed on sociocultural, religious and moral reasons, and aspects for extensive censorship of media resources in the Arab countries. This article aims to fill these lacunae, and offer an explanatory scheme for the formation and implementation of Internet censorship in the Arab world.

\section{Legal Basis for Internet Censorship in the Arab Countries}

The philosophy of the Internet is to make it as free as possible from any government or other interference, which is furthered by its technical features, allowing it to continue to function even if servers are knocked offline. However, it is impossible to completely abandon Internet governance or regulation of its infrastructure, since the Internet is a kind of mirror reflecting the real world. There are 
norms in the real world, including legal ones, designed to ensure freedom of speech and the right of access to information, while protecting against abuse of these rights and unlawful behaviour.

In Arab countries, the problem of freedom of speech and the right to access information on the Internet is quite acute. This is largely because the positions of Islam in the countries of the Middle East and North Africa are not only strong, but are fundamental ${ }^{1}$, and have determined the trends of social development over many centuries. At the same time, the very problem of human rights, in general, and freedom of speech and the right of access to information, in particular, are fairly new to Muslim legal thought.

One Russian specialist in the field of Islamic law, Leonid Syukiyainen, rightly notes that "modern Islamic jurisprudence turned to the development of its own position on human rights relatively recently. Its appearance was a reaction of Muslim thought to the adoption of international human rights instruments, which generally reflected a liberal view on this issue. The views of modern Muslim authors on the relationship of Islamic landmarks with liberal standards of human rights are not unanimous" (Syukiyainen 2012, p. 118). In addition, it is known that during the discussion of the Universal Declaration of Human Rights at the General Assembly of the United Nations in 1948, the Egyptian delegation was very cautious about Article 19, which provides for freedom of thought and belief, stating that such an approach can be viewed as "encouraging, though not deliberately, certain machinations of missions well known in the East, aimed at converting the masses of the population of the East into their faith" (UN General Assembly 1948, p. 913).

The sources of Muslim law do not contain clearly defined norms regulating freedom of speech. Many Muslim jurists (see: Khalifa 1992; Al'-Roshd 2008) derive this right from the following Qur'anic verse:

and do not argue with the People of the Scripture except in a way that is best (29:46).

One of the most respected Muslim jurists, Yusuf Karadayi, deduces freedom of thought based on the following verses of the Qur'an:

I only advise you of one [thing] — that you stand for Allah, [seeking truth] in pairs and individually, and then give thought (34:46).

Observe what is in the heavens and earth (10:101).

However, in this context, the most eloquent is the following hadith:

The best Jihad is to say a word of truth before a tyrant ruler. (Al'-Roshd 2008, p. 70)

Thus, the concept of freedom of speech in Muslim law is not clearly defined, but two aspects that are most important should be fixed. Initially, Shari'ah allowed the possibility of expressing one's own opinion but, at the same time, a limiting factor was introduced, and it was very widely and subjectively interpreted, obliging to enter the discussion "in the best way". This obligation enables modern legislators in Arab countries to significantly restrict freedom of speech, making it necessary to follow the norms of morality and ethics. In this regard, the example of Kuwait where, in 2006, the law on printed publications and dissemination of information was adopted, is indicative. In accordance with this law, any material encroaching on the acts and attributes of Allah, injuring the honor of the prophets recognized by Islam, the companions of the Prophet Muhammad and members of his family, as well as representing the dogmatic foundations of Islam in a negative light, are prohibited (Syukiyainen 2012). Thus, the norms of morality and religious righteousness are a priori set over certain rights in their liberal legal sense.

1 One should bear in mind that, despite the fact that in the Arab countries there is ethno-confessional diversity and there are multi-part societies (like Lebanon, for example), Sunni Islam is the dominant religious identity there. 
Now let us turn to the official documents adopted at the regional level in the Muslim world. In 1981, the Islamic Council of Europe adopted the Universal Islamic Declaration of Human Rights. Article 12 of this document read as follows:

(a) Every person has the right to express his thoughts and beliefs so long as he remains within the limits prescribed by the Law. No one, however, is entitled to disseminate falsehood or to circulate reports which may outrage public decency, or to indulge in slander, innuendo or to cast defamatory aspersions on other persons.

(b) There shall be no bar on the dissemination of information provided it does not endanger the security of the society or the state and is confined within the limits imposed by the Law.

(c) No one shall hold in contempt or ridicule the religious beliefs of others or incite public hostility against them; respect for the religious feelings of others is obligatory on all Muslims (Universal Islamic Declaration of Human Rights 1981).

Article 22 of the Cairo Declaration of Human Rights, also adopted within the Organization of the Islamic Conference in 1990, directly linked freedom of speech with the need to follow Shari'ah norms:

(a) Everyone shall have the right to express his opinion freely in such manner as would not be contrary to the principles of the Shari'ah.

(b) Everyone shall have the right to advocate what is right, and propagate what is good, and warn against what is wrong and evil according to the norms of Islamic Shari'ah.

(c) Information is a vital necessity to society. It may not be exploited or misused in such a way as may violate sanctities and the dignity of Prophets, undermine moral and ethical Values or disintegrate, corrupt or harm society or weaken its faith (Cairo Declaration on Human Rights in Islam 1990).

All of this testifies that the necessity to bring any information into conformity with Shari'ah norms or national legislation is very clearly recognized at the international level. At the same time, the overwhelming majority of the constitutions of Arab countries, fixing the right of citizens to freedom of speech, make reference to the need to follow additional regulatory and legal acts.

Thus, Article 15 of the Constitution of The Hashemite Kingdom of Jordan states:

The State shall guarantee freedom of opinion. Every Jordanian shall be free to express his opinion by speech, in writing, or by means ofphotographic representation and other forms of expression, within the limits of the law.

Freedom of the press and publications shall be ensured within the limits of the law.

Newspapers shall not be suspended from publication nor their permits be withdrawn except in accordance with the provisions of the law. (Constitution of The Hashemite Kingdom of Jordan 1952)

And Article 43 of the 2012 Constitution of the Syrian Arab Republic reads:

The state shall guarantee freedom of the press, printing and publishing, the media and its independence in accordance with the law. (Constitution of the Syrian Arab Republic 2012)

Most of the constitutions of the Arab countries, in their first articles, contain references to the norms of Shari'ah as the basis of legislation. These primarily include the constitutions of the Arabian monarchies (Article 1, Qatar; Article 2, Bahrain; Article 2, Oman; Article 7, UAE, Article 3, Yemen; and Article 2, Egypt). For example, Article 2 of Kuwait's constitution states:

The religion of the State is Islam, and Islamic Law shall be a main source of legislation. (Kuwait's Constitution of 1962 1962)

And Article 1 of the Libyan Interim Constitutional Declaration of 2011 directly indicates that: 
"the main source of legislation is Islamic law (Shari'ah)". (Libyan Interim Constitutional Declaration 2011)

Moreover, in all Arab constitutions, citizens retain the right to freedom of speech and access to information (e.g., Article 48 of the constitution of Qatar; Articles 30 and 31 of the UAE constitution; Article 8 of the Tunisian constitution). At the same time, in a number of countries, legislators deliberately introduced significant limitations to the relevant provisions of the constitutions:

The freedom of the press, printing, and publishing is guaranteed according to the terms and conditions prescribed by the Law. Anything that leads to discord, affects the security of State, or prejudices human dignity or rights, is prohibited. (article 31 of Oman's constitution) (Oman's Constitution 1996)

Freedom of opinion and scientific research is guaranteed. Everyone has the right to express his opinion and publish it by word of mouth, in writing or otherwise under the rules and conditions laid down by law, provided that the fundamental beliefs of Islamic doctrine are not infringed, the unity of the people is not prejudiced, and discord or sectarianism is not aroused. (article 23 of Bahrain's constitution) (Bahrain's Constitution 2002)

The state shall guarantee the freedom and confidentiality of mail, telephone, telegram and all other means of communication, none of which may be censored, searched, exposed, delayed or confiscated except in cases specified by law and according to a court order. (article 53 of Yemen's constitution) (Yemen's Constitution 1991)

The 2005 constitution of Iraq is also highly ambiguous regarding freedom of speech. According to its Article 38,

The State shall guarantee in a way that does not violate public order and morality:

First. Freedom of expression using all means.

Second. Freedom of press, printing, advertisement, media and publication. (Iraq's Constitution 2005)

At the same time, Article 2, paragraph (a) says that:

No law may be enacted that contradicts the established provisions of Islam. (Iraq's Constitution 2005)

Similarly, Article 28 of Morocco's constitution reads that:

The freedom of the press is guaranteed and may not be limited by any form of prior censure. (Morocco's Constitution 2011)

While the same article also states that

All have the right to express and to disseminate freely and within the sole limits expressly provided by the law, information, ideas and opinions. (Morocco's Constitution 2011)

Thus, there is an obvious legal conflict: on the one hand, the state completely rejects any manifestation of censorship and, on the other, it refers to the relevant legal acts designed to regulate information flows.

The experience of Egypt in the times of Hosni Mubarak is also interesting. Article 48 of the Egyptian constitution prohibited censorship of the mass media:

Freedom of the press, printing, publication and mass media shall be guaranteed. Censorship on newspapers is forbidden. Warning, suspension or abolition of newspapers by administrative means are prohibited. However, in case of declared state of emergency or in time of war, limited censorship may be imposed on newspapers, publications and mass media in matters related to public safety or for purposes of national security in accordance with the law. (Egypt's Constitution 1971) 
In this regard, it is interesting to recall the fact that, from 1967, until the events of the Arab Spring, Egypt was in a state of emergency, with the exception of an 18-month break in 1980-1981. Therefore, the state had the full right to censor the media, while relying on the norms of the current constitution.

Among the Arab countries, only the Algerian constitution stands apart, containing no articles on the use of Shari'ah as the basis of legislation, and also no reservations regarding freedom of expression:

The freedom of conscience and the freedom of opinion are inviolable. (Constitution of Algeria 2006)

Algeria is an exception, largely as a result of a bloody civil war in the 1990s between the parties defending the transition to an Islamic republic, and religious factions and the military establishment that advocated the preservation of a secular state. The victory of the latter led to the fact that, in post-conflict Algeria, it was decided to completely avoid references to religion.

Thus, legislators in Arab countries intentionally restrict freedom of expression, directly or indirectly, by referring to the norms of the relevant legal acts. At the same time, there are no special laws regulating the dissemination of information on the Internet in Arab countries (in practice, such laws are quite rare in the world today). Thus, this kind of activity is often subject to special laws regulating the activities of traditional media that could be controlled more effectively than new media.

However, due to the specific features of their functioning, new media do not fall under the existing control mechanisms applied to traditional mass media. For example, in the Arab countries, a number of typical restrictions are applied to control the media-required licenses, high insurance premiums, etc. For example, in Bahrain, a license is issued by the Ministry of Information after approval by the Council of Ministers and, in Libya, the director of the press department has the right to approve or reject any license after discussion with the Minister of Information. In Syria, at least before the start of the civil war, a license might be issued after the decision of the Council of Ministers, but the prime minister might reject approval for publication, as well as refuse to nominate any person to the post of owner, manager, and chief editor of the publication, if it could be proven that any of them supported the unconstitutional situation in the country. In Tunisia, under Ben Ali, an application for licensing was submitted to the Minister of the Interior, and then to the Minister of Information. In Egypt, the publication of a newspaper is the exclusive right of political parties or corporations in the private and public sectors. An application for licensing is submitted to the Supreme Council of Journalists, which must consider it within 40 days. Corporations should be cooperatives or stock companies whose registered shares are owned by Egyptians. The formation of these corporations is possible only with the approval of the Council of Ministers which, in turn, consults with the Minister of Economy (Saab 2006, p. 512).

High insurance premiums are also a serious barrier. For example, to obtain a license in Bahrain, it is required to pay from 3000 to 5000 Bahraini dinars, ${ }^{2}$ in Egypt, this amount ranges from 100,000 to 1,000,000 Egyptian pounds ${ }^{3}$; and, in Kuwait, it ranges from 1000 to 4000 Kuwaiti dinars; ${ }^{4}$ depending on the type of publication. Moreover, in Bahrain, "all Internet services providers are indirectly controlled by the government through orders from the Telecommunications Regulation Authority (TRA)" (Freedom House 2015).

Of course, such forms of restriction of media freedom cannot affect the activities of new media operating in a virtual environment, which do not require licensing, payment of insurance premiums, and other types of fees. In this regard, information on the Internet in Arab countries is subject to censorship post factum, based on the content of the published content.

In Saudi Arabia, freedom of expression is guaranteed within the framework of legal and religious rules but, in exceptional situations, the media are subject to complete censorship. Any publication

\footnotetext{
8000-13,000 USD.

$15,000-150,000$ USD.

500-14,000 USD.
} 
may be banned in Qatar by decision of the head of the department of publications for a period of three months. In Lebanon, in extreme situations, when there is a threat to national security, public order, and the safety of citizens, all media are subject to censorship, provided for by an agreement issued by the Council of Ministers (agreement No. 104 of 1977, supplemented by act No. 89/91 and act No. 330/94). Thus, dozens of sites had been blocked annually due to the immoral content including pornography, prostitution, etc. (SMEX 2015). In Egypt, Law No. 96 of 1996 states that media censorship is permitted only in the event of hostilities or a state of emergency. Egyptian law gives the president or his deputy the power to refer the case of any information source to the court to find out how dangerous the material is while the country is in a state of emergency or military action (Sukhova 2008, p. 192).

\section{Internet Censorship in the Arab World}

In recent years, a number of studies conducted comparative analyses of Internet censorship in various countries of the world. Thus, within the framework of the project "OpenNet Initiative," a database was created for 74 countries of the world, according to which a rating of states was made depending on the degree of filtering of websites on political subjects (OpenNet Initiative 2009; Reporters Without Borders 2016). According to these data, the highest level of Internet censorship is observed in China, India, Iran, and Turkmenistan. Arab countries, although not being the most censoring states in the world, in some cases demonstrate a different approach to this issue. The only country with ubiquitous Internet filtering in 2011 was Syria, which is not surprising, because the country has actually been in a state of full-fledged civil war since the beginning of 2011. In this case, Arab news sites that support the Syrian opposition abroad, as well as Kurdish organizations, were subject to censorship. In addition, access to the ".il" domain (Israel) was completely closed.

Countries such as Saudi Arabia, and the United Arab Emirates, fall into the category of countries with a significant level of Internet censorship. At the same time, the authorities of Saudi Arabia and the UAE have resorted to censoring Internet traffic through the Secure Computing system, which developed software and services for filtering websites. It is interesting that this company, specializing in the creation of Internet security products, was based in San Jose (California) and, in 2008, was taken over by another American company, McAfee. Thus, software for filtering web pages in Saudi Arabia and the United Arab Emirates was supplied by a company in the United States. The filtering of Internet traffic, itself, in these countries, is mainly in areas such as pornography, drugs, and religious distortions of Islam.

A selective level of website filtering is present in Libya, Sudan, Kuwait, Bahrain, Oman, Mauritania, Qatar, and Jordan, while, Internet censorship is completely absent in Egypt, Algeria, Iraq, Tunisia, and Morocco.

There are three basic prerequisites for filtering web pages:

- $\quad$ to maintain political stability (Libya, Jordan);

- $\quad$ to strengthen national security (Morocco);

- $\quad$ to preserve traditional social values (Oman).

However, many Arab countries are simultaneously guided by several of these reasons. Hence, all three directions of censorship on the Internet are relevant for Saudi Arabia, Syria, Tunisia, and the United Arab Emirates. The issues of preserving traditional values and political stability most concern the governments of Jordan and Libya. ${ }^{5}$ And, with the aim of strengthening national security and preserving traditional social values, Yemen is implementing Internet censorship in the times of Ali Abdulla Saleh. In recent years, after the beginning of the military intervention of the Coalition led by Saudi Arabia, the shutdown of the Internet in the territories controlled by the Houthis has become more frequent in North Yemen (IFEX 2017).

5 Specifically, the Gaddafi regime in Libya. 
Another study was conducted by the Civil Society Development Fund which, based on the commonality of tasks and arguments that countries used to justify interference in the Internet as well as the similarity of tools for their implementation, described five models of Internet censorship: Asian, Middle Eastern, Restriction, Continental, and Liberal (Civil Society Development Fund 2013). Two of these models, Middle Eastern and Restriction, are applicable to Arab countries.

The Middle Eastern model of Internet censorship is implemented by countries including Saudi Arabia, the United Arab Emirates, Qatar, Bahrain, Oman, and Yemen. Its distinguishing feature is the selection of religion as a determining factor when governments conduct website filtering. At the same time, as mentioned above, the main sites that are subject to censorship are those with content that contradicts the existing values and norms of morality, as well as encroaching upon the dominant religion, Islam.

The restriction model is implemented by only one Arab country, Syria; it is also used by countries including Iran, Uzbekistan, and Ethiopia. Its characteristic feature is the filtering of Internet resources belonging to, or sympathizing with, the radical political opposition, as well as human rights organizations.

Several other models can be singled out-in particular, the Moroccan-Jordanian model, which reveals the potential for the current political power to quickly resolve conflicts by peaceful means, and a high degree of traditionalism in the political culture that explains the unlimited ruler in power, a direct descendant of the Prophet Mohammed. In Morocco, censorship is quite common, but there is no legislation or special codes regulating the control of virtual space; Web sites are blocked if they affect one of the three "taboo topics for Morocco: the king, Islam and the status of Western Sahara" (Sukhov 2013, p. 249). In Jordan, specific network resources are also monitored; it is common practice to monitor users of Internet cafes with cameras, and there is also a requirement to register personal data and IP addresses. The main focus of censorship is political issues (Dalek et al. 2018; Haselton 2013); this focus may be related to the geographical proximity of the country to such potentially conflicting territories as Israel, Iraq, Palestine, Lebanon, and Syria.

In the monarchies of the Persian Gulf, the level of spread of the Internet is one of the highest in the entire region, but access to Internet technologies is strictly controlled. In some countries (including the UAE and Saudi Arabia), special laws have been introduced that regulate Internet activity. Hence, for example, federal information law in these countries criminalizes hacking, insulting religious shrines and rituals, discussing the contradictions of the Islamic religion, and abuse of family values and principles. A similar situation is observed in Oman and Kuwait. Like other states in the Middle East and North Africa, the Gulf countries are also in the habit of blocking sites on suspicion of "immorality".

As for Internet filtering methods, in the countries of the Middle Eastern model of censorship, mainly Western software is used-“Netsweeper" (Qatar, UAE, Yemen, Bahrain) (Dalek et al. 2018) and "Smartfilter" (Oman, Tunisia, Saudi Arabia)—which leaves the compilation and updating of blocklists in the hands of the software company. At the same time, the disadvantage of this model is the focus on blocking English-language resources, and then in Arabic (Haselton 2013). Another distinctive feature of the countries associated with the Middle Eastern model of Internet censorship is the widespread arrests of bloggers and their criminal prosecution for spreading materials that threaten the ruling regime under the pretext of their encroachment on public values.

However, it is worth noting that most Arab countries profess this method to some extent. Criticism of the Muslim religion and way of life, attempts at the satirical perception of Islamic prophets, as well as pornography, homosexuality, and drug addiction, are extremely negatively perceived in all countries of the Arab world, and those perceived as spreading information along these lines are subject to very harsh punishment in accordance with the criminal legislation of these countries. The problem is that benevolent intentions to protect the Arab society from moral decay hide the goal of keeping power in the hands of the ruling regime (Howard et al. 2011a). 


\section{Policy vs. Morality}

In general, it is worth noting that censorship of the media for Arab countries is one of the fundamental characteristics of the development of these societies, largely due to the strong position of the Islamic religion in the region; however, Internet censorship in Arab countries is conducted on several grounds.

There may be political reasons: when this is the case, the access of the population to sites that contain information representing a potential threat to the current government is restricted; prohibited content may be useful to regimes in allowing discontents to be expressed relatively harmlessly, and keeping rulers informed about that critics are thinking. In some cases, sites of a religious nature can also be considered potential threats and, thus, be blocked. However, the main reason for controlling the virtual space becomes the protection of social norms and morality, primarily as it concerns the fight against child pornography and prevention of the incitement of ethnic hatred. In addition, web resources may be subject to censorship for security reasons, e.g., sites related to terrorist and other extremist groups are blocked.

Communication networks in the countries of the Middle East and North Africa have historically been closely monitored by the state, which is considered by some World Bank experts to be one of the key factors hindering the region's economic growth (Terrab et al. 2004). Reports from the OpenNet Initiative and Reporters Without Borders on these countries repeatedly note the use of various methods of control and supervision in the virtual space by the authorities, including limiting the speed of data transfer, filtering electronic messages, and monitoring potentially dangerous websites (Silver and Elgin 2011). Despite the rather strict regulation of the Internet space and the control of specific resources in Arab countries, the complete blocking of communications during the mass protests of the Arab Spring has become a fundamentally new mechanism of interaction between the authorities and the opposition.

The events of the Arab Spring are very significant in this context, during which restrictions on the freedom to use the Internet, in some cases served, as a direct reason for starting demonstrations, and were also used by the authorities as a tool for suppressing insurgency; at the same time, mechanisms of a technical and violent nature were used to control the content of certain resources, primarily opposition ones.

In practice, the Arab regimes were subjected to numerous criticisms for the fact that, under the pretext of protecting the moral foundations of society, they actually censored the political rights of citizens. The preservation of traditional social values, in this case, became only a façade for the true intentions of the Arab dictators: the suppression of political pluralism and of self-expression on the Internet.

In this regard, it is interesting to refer to data from the Internet resource Google Trends-a public web application based on Google search that shows how often a specific term is searched for in relation to the total volume of search queries in different regions of the world and in different languages. This system shows the frequency of hits on a particular query in the Google search engine in a particular country at a given time interval. Although this tool has some limitations (it does not allow, for example, working with more specific data), it is applicable to a wide range of themes including business, medicine, or to measure a variety of behaviors (Mayer 2010; Stephens-Davidowitz 2012; etc.), and seems relevant if we compare the search volume of different queries over time. More than that, this resource provides an opportunity to find out the level of interest of citizens with regard to a given issue. For example, the website of a political movement can be blocked by the authorities; however, if the movement itself does not engage the interest of the population, it is hardly appropriate, in this case, to talk about the serious impact of censorship on the realization of the political rights of citizens.

However, after the resignation of Hosni Mubarak and a significant decrease in the censorship of the Internet space in Egypt, there was no increase in the growth of requests for previously forbidden resources of a political nature. However, as shown in Figure 1, requests for pages containing pornographic content rose sharply immediately after the 25 January revolution. 
July 2010-December 2010

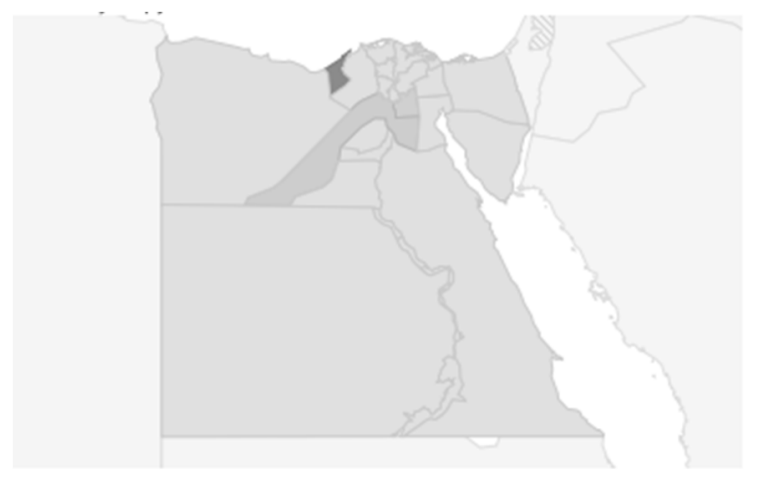

January 2011-June 2011

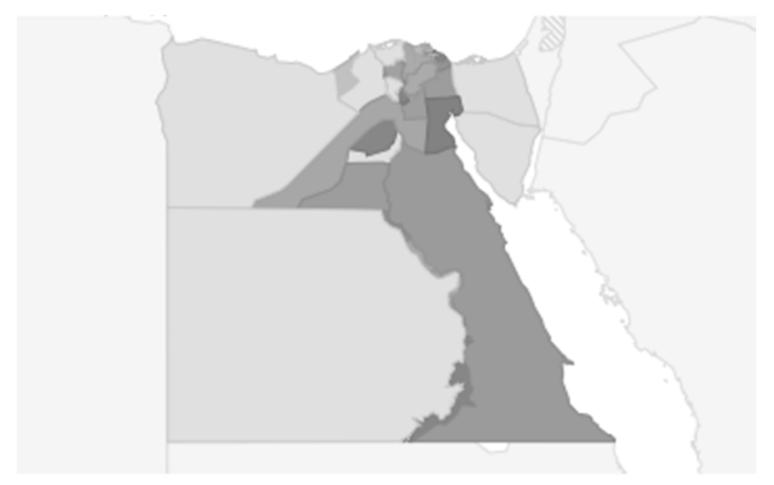

Figure 1. The dynamics of Google's search queries in Egypt for the word "porno" (by province) *. * The darkest coloring corresponds with the highest number of requests. Source: (Google Trends 2018).

In the first half of 2011, there was a sharp increase in requests for Internet sites with content that would be considered immoral (Figure 1), while requests for websites of previously banned political movements remained at a level similar to the pre-revolutionary years. We emphasize, once again, that these maps do not show the absence (or presence) of censorship on the Internet in the countries in question but, instead, demonstrate the interest of citizens in specific types of content.

Thus, we can conclude that the actions of governments to filter virtual resources in accordance with the moral and ethical attitudes of their countries were not without justification. As we have just shown, the interest in prohibited resources, in particular, of a pornographic nature, increased significantly immediately after the removal of restrictions on access to them. However, there was no significant increase in interest in political issues, which indicates the significant role of the "routine" bias of Internet users, rather than the opposition biases. It is often the restriction of the usual informational bias of the majority of the population that is considered a powerful catalyst for demonstrations-the removal of such prohibitions creates some level of stabilization of the unrest due to the temporary satisfaction of informational needs or desires.

At the same time, we should not forget that the periods of the greatest popularity of Internet resources clearly coincided with the peaks of protest activity, which is particularly clearly seen in the example of Facebook (Howard et al. 2011b). This suggests that, in the modern world, new methods of communication and information transfer are actively involved with the interaction of social and political processes, creating new channels and techniques for interaction between the authorities and society, and the study and proper use of such channels can reduce the risks of political destabilization.

Author Contributions: L.I. proposed a legal approach in its connection to the moral aspects of censorship while A.S. regarded new information technologies as a sublect of censorship and a field of counteraction between religion and morality. The conclusions were made jointly by both authors.

Funding: This article is an output of a research project implemented as part of the Basic Research Program at the National Research University Higher School of Economics (HSE) in 2018 with support by the Russian Science Foundation (Project No. 18-18-00254).

Conflicts of Interest: The authors declare no conflict of interest.

\section{References}

Abdulla, Rasha A. 2007. The Internet in the Arab World: Egypt and Beyond. New York: Peter Lang.

Aday, Sean, Henry Farrell, Marc Lynch, John Sides, and Deen Freelon. 2012. New Media and Conflict after the Arab Spring. United States Institute of Peace, Peceworks 80: 1-24.

Al'-Roshd, Said M., ed. 2008. Khadisy Proroka [Hadith of the Prophet]. Perevod i kommentarii I.V. Porokhovoy. 2-ye izd. Moscow: Avanta+.

Al-Kandari, Ali, and Mohammed Hasanen. 2012. The impact of the Internet on political attitudes in Kuwait and Egypt. Telematics and Informatics 29: 245-53. [CrossRef] 
Allagui, Ilhem, and Johanne Kuebler. 2011. The Arab Spring and the Role of ICTs. Introduction. International Journal of Communication 5: 8.

Altermann, John B. 1998. New Media, New Politics? From Satellite Television to the Internet in the Arab World. Washington, DC: The Washington Institute for Near East Policy.

Anderson, John W. 2003. New media, new publics: Reconfiguring the public sphere of Islam. Social Research 70: 887-906.

Arab IP Centre. 2013. Use of Internet in the Arab World. Available online: http:/ / www.arabipcentre.com/use-ofinternet-in-the-arab-world.php (accessed on 5 June 2018).

Arab Social Media Report. 2011. Available online: http://interactiveme.com/2011/06/twitter-usage-in-themena-middle-east/ (accessed on 30 December 2017).

Armando, Salvatore. 2013. New Media, the "Arab Spring," and the Metamorphosis of the Public Sphere: Beyond Western Assumptions on Collective Agency and Democratic Politics. Constellations 20: 217-28.

Ayubi, Nazih. 2003. Political Islam: Religion and Politics in the Arab World. London: Routledge.

Bahrain's Constitution. 2002. Manama. Available online: https://www.constituteproject.org/constitution/ Bahrain_2002.pdf (accessed on 13 November 2018).

Bureau of Democracy, Human Rights, and Labor. 2016. Country Reports on Human Rights Practises for 2016. Available online: https:/ / www.state.gov/j/drl/rls/hrrpt/2016humanrightsreport/index.htm?year=2016\& dlid=265494\#wrapper (accessed on 7 November 2018).

Cairo Declaration on Human Rights in Islam. 1990. Cairo. Available online: http://www.bahaistudies.net/ neurelitism/library/Cairo_Declaration_on_Human_Rights_in_Islam.pdf (accessed on 7 November 2018).

Calingaert, Daniel. 2010. Authoritarianism vs. the Internet. Policy Review 160: 63.

Civil Society Development Fund. 2013. Fil'tratsiya kontenta v Internete. Analiz mirovoy praktiki [Content Filtering on the Internet. Analysis of World Practice]. Available online: http://civilfund.ru/Filtraciya Kontenta_V_Internete_Analiz_Mirovoy_Praktiki.pdf (accessed on 10 October 2018).

Constitution of Algeria. 2006. Alger. Available online: https:/ /law.wustl.edu/GSLR/CitationManual/countries / algeria.pdf (accessed on 7 November 2018).

Constitution of The Hashemite Kingdom of Jordan. 1952. Amman. Available online: http://www.wipo.int/ wipolex/en/text.jsp?file_id=227814 (accessed on 7 November 2018).

Constitution of the Syrian Arab Republic. 2012. Damascus. Available online: http://www.voltairenet.org/ article173033.html (accessed on 7 November 2018).

Dainotti, Alberto, Claudio Squarcella, Emile Aben, Kimberly C. Claffy, Marco Chiesa, Michele Russo, and Antonio Pescapé. 2011. Analysis of country-wide internet outages caused by censorship. Paper presented at the 2011 ACM SIGCOMM Conference on Internet Measurement Conference, Berlin, Germany, November 2-4; pp. 1-18.

Dalek, Jacub, Lex Gill, Bill Marczak, Sarah McKune, Naser Noor, Joshua Oliver, John Penney, Adam Senft, and Ron Deibert. 2018. Planet Netsweeper. Executive Summary. Available online: https:/ / citizenlab.ca/2018/ 04/planet-netsweeper/ (accessed on 7 November 2018).

Deibert, Ron J. 2009. The geopolitics of internet control. Censorship, sovereignty, and cyberspace. In Routledge Handbook of Internet Politics. Edited by Andrew Chadwick and Philip N. Howard. London: Taylor \& Francis, pp. 323-36.

Diamond, Larry J. 2012. Liberation Technology: Social Media and the Struggle for Democracy. Baltimore: Johns Hopkins University Press.

Egypt's Constitution. 1971. Cairo. Available online: http://www.palatauruscentrostudi.eu/doc/EGY Constitution_1971_EN.pdf (accessed on 7 November 2018).

Freedom House. 2011. Freedom on the Net 2011. Available online: https:/ / freedomhouse.org/report/freedomnet/freedom-net-2011 (accessed on 13 September 2018).

Freedom House. 2015. Bahrain Freedom on the Net 2015. Available online: https://freedomhouse.org/report/ freedom-net/2015/bahrain (accessed on 7 November 2018).

Freedom on the Net. 2018. The Rise of Digital Authoritarianism. Available online: https: / / freedomhouse.org/ report/freedom-net/freedom-net-2018/rise-digital-authoritarianism (accessed on 7 November 2018).

Google Trends. 2018. Available online: https:/ /www.google.ru/trends/explore (accessed on 24 April 2018). 
Haselton, Bennett. 2013. Smartfilter. Miscategorization and Filtering in Saudi Arabia and UAE. Available online: https:/ / citizenlab.ca/2013/11/smartfilter-miscategorization-filtering-saudi-arabia-uae/ (accessed on 7 November 2018).

Herrera, Linda. 2012. Youth and Citizenship in the Digital Age: A View from Egypt. Harvard Educational Review 82: 333-52. [CrossRef]

Hofheinz, Albrecht. 2005. The Internet in the Arab world: Playground for political liberalization. International Politics and Society 3: 78-96.

Houissa, Ali. 2000. The Internet predicament in the Middle East and North Africa: Connectivity, access and censorship. Journal of Librarianship and Information Science 32: 56-63. [CrossRef]

Howard, Philip N. 2010. The Digital Origins of Dictatorship and Democracy: Information Technology and Political Islam. New York: Oxford University Press.

Howard, Philip N., and Malcolm R. Parks. 2012. Social media and political change: Capacity, constraint, and consequence. Journal of Communication 62: 359-62. [CrossRef]

Howard, Philip N., Sheetal D. Agarwal, and Muzammil M. Hussain. 2011a. When do states disconnect their digital networks? Regime responses to the political uses of social media. The Communication Review 14: 216-32. [CrossRef]

Howard, Philip N., Aiden Duffy, Deen Freelon, Muzammil M. Hussain, Will Mari, and Marwa Maziad. 2011b. Opening Closed Regimes: What Was the Role of Social Media during the Arab Spring? ITPI Working Paper. Available online: https:/ / deepblue.lib.umich.edu/bitstream/handle/2027.42/117568/2011_Howard-DuffyFreelon-Hussain-Mari-Mazaid_PITPI.pdf?sequence=1\&isAllowed=y\%20 (accessed on 7 November 2018).

Human Rights Watch. 1999. The Internet in the Mideast and North Africa: Free Expression and Censorship. New York: Human Rights Watch.

IFEX. 2017. Why Yemen's Internet Shutdowns Are so Dangerous to Civilians. Available online: https:/ /www.ifex. org/yemen/2017/12/11/internet-shutdown-houthis / (accessed on 7 November 2018).

Inglehart, Ronald, and Wayne E. Baker. 2000. Modernization, cultural change, and the persistence of traditional values. American Sociological Review 65: 19-51. [CrossRef]

Internet World Stats. 2015. Internet Usage in the Middle East. Available online: http:/ / www.internetworldstats. com/stats5.htm (accessed on 5 June 2018).

Iraq's Constitution. 2005. Baghdad. Available online: https:/ /www.constituteproject.org/constitution/Iraq_2005. pdf?lang=en (accessed on 7 November 2018).

Jansen, Fieke. 2010. Digital activism in the Middle East: Mapping issue networks in Egypt, Iran, Syria and Tunisia. Knowledge Management for Development Journal 6: 37-52. [CrossRef]

Karolak, Magdalena M. 2011. Civil Society and Web 2.0 Technology: A Study of Social Media in the Kingdom of Bahrain. Arab Media E Society 13: 1-18. Available online: http:/ / www.arabmediasociety.com / ?article=773 (accessed on 26 September 2018).

Khalifa, Rashad. 1992. Qur'an. The Final Testament. Authorized English Version. Tucson: Islamic Productions.

Khazen, Jihad. 1999. Censorship and state control of the press in the Arab world. Harvard International Journal of Press/Politics 4: 87-92. [CrossRef]

Kuwait's Constitution of 1962. 1962. Kuwait. Available online: https://www.constituteproject.org/constitution/ Kuwait_1992.pdf?lang=en (accessed on 7 November 2018).

Langman, Lauren, and Morris Douglas. 2002. Internet Mediation: A Theory of Alternative Globalization Movements. Proceedings of the 1st International Workshop on Community Informatics; Edited by M. Gurstein and S. Finquelievich. Montreal. Available online: http:/ / www.csudh.edu/dearhabermas/langmanbk01.htm (accessed on 2 September 2018).

Lerner, Melissa Y. 2010. Connecting the actual with the virtual: The Internet and social movement theory in the Muslim world-The cases of Iran and Egypt. Journal of Muslim Minority Affairs 30: 555-74. [CrossRef]

Libyan Interim Constitutional Declaration. 2011. Tripoli. Available online: https:/ /www.constituteproject.org/ constitution/Libya_2011.pdf (accessed on 7 November 2018).

Lifintseva, Tatyana P., Leonid M. Issaev, and Alisa R. Shishkina. 2015. Fitnah: The Afterlife of a Religious Term in Recent Political Protest. Religions 6: 527-42. [CrossRef]

Mayer, Catherine. 2010. Study: Are Google Searches Affecting the Stock Market? Time Magazine. November 15. Available online: http:/ / newsfeed.time.com/2010/11/15/google-searches-and-financial-market-fluctuations-linkedand-worrying/ (accessed on 7 November 2018). 
Middle East Voices. 2012. Samsung, iPhone, Nokia and the Next Arab Spring. Available online: http:/ / middleeastvoices.voanews.com/2012/05/samsung-iphone-nokia-and-the-next-arab-spring46703/ (accessed on 15 April 2018).

Moore, Jina. 2011. Did Twitter, Facebook Really Build a Revolution? Christian Science Monitor. June 30. Available online: http:/ / www.nbcnews.com/id/43596216/ns/technology_and_science-christian_science_monitor/ t/did-twitter-facebook-really-build-revolution/ (accessed on 30 June 2018).

Morocco's Constitution. 2011. Rabat. Available online: https://www.constituteproject.org/constitution/ Morocco_2011?lang=en (accessed on 14 November 2018).

Newsom, Victoria A., and Lengel Lara. 2012. Arab Women, Social Media, and the Arab Spring: Applying the framework of digital reflexivity to analyze gender and online activism. Journal of International Women's Studies 13: 31-45.

Oman's Constitution. 1996. Muscat. Available online: https:/ /www.constituteproject.org/constitution/Oman_ 2011?lang=en (accessed on 14 November 2018).

OpenNet Initiative. 2009. Internet Filtering in the Middle East and North Africa. Available online: https: / / opennet.net/sites / opennet.net/ files/ONI_MENA_2009.pdf (accessed on 24 December 2017).

Reporters Without Borders. 2016. No Concessions to Media as Indiscriminate Repression Continues in Countries with Pro-Democracy Protests. Available online: https://rsf.org/en/news/no-concessions-mediaindiscriminate-repression-continues-countries-pro-democracy-protests (accessed on 12 April 2017).

Saab, Edmond. 2006. The Independence of the Arab Media. In Arab Media in the Information Age. Abu Dhabi: The Emirates Center for Strategic Studies and Research.

Shishkina, Alisa R., and Leonid M. Issaev. 2015. Internet Censorship in Arab Countries. Aziya i Afrika Segodnya 2: 40-45.

Silver, Vernon, and Ben Elgin. 2011. Torture in Bahrain Becomes Routine with Help from Nokia Siemens. Available online: http:/ / www.bloomberg.com/news/2011-08-22/torture-in-bahrain-becomes-routine-with-helpfrom-nokia-siemens-networking (accessed on 13 September 2018).

SMEX. 2015. Mapping Blocked Websites in Lebanon 2015. Available online: https://smex.org/mapping-blockedwebsites-in-lebanon-2015/ (accessed on 6 November 2018).

Stepanova, Ekaterina. 2011. The role of information communication technologies in the "Arab spring". Ponars Eurasia 15: 1-6.

Stephens-Davidowitz, Seth. 2012. How Racist Are We? Ask Google. The New York Time. June 9. Available online: https: / campaignstops.blogs.nytimes.com/2012/06/09/how-racist-are-we-ask-google/ (accessed on 7 November 2018).

Sukhov, Nikolay V. 2013. «Politicheskaya vesna» v Marokko [“Political Spring” in Morocco]. In Sistemnyy Monitoring Global'nykh i Regional'nykh Riskov: Arabskiy mir Posle Arabskoy Vesny. Edited by Andrey V. Korotayev, Leonid M. Issaev and Alisa R. Shishkina. Moscow: Librokom.

Sukhova, Elena F. 2008. Vliyaniye pravitel'stva na deyatel'nost' arabskikh SMI [The influence of the government on the activities of the Arab media]. Vestnik Nizhegorodskogo Universiteta im. N.I. Lobachevskogo. Seriya: Mezhdunarodnyye Otnosheniya, Politologiya, Regionovedeniya 1: 190-93.

Swigger, Nathaniel. 2013. The online citizen: Is social media changing citizens' beliefs about democratic values? Political Behavior 35: 589-603. [CrossRef]

Syukiyainen, Leonid R. 2012. Sovremennyye religioznyye kontseptsii prav cheloveka: sopostavleniye teologicheskogo i yuridicheskogo podkhodov [Modern religious concepts of human rights: a comparison of theological and legal approaches]. In Prava Cheloveka Pered Vyzovami XXI Veka. Edited by William V. Smirnov and Alexander Y. Sungurov. Moscow: Rossiyskaya assotsiatsiya politicheskoy nauki (RAPN); Rossiyskaya politicheskaya entsiklopediya (ROSSPEN).

Szajkowski, Bogdan. 2011. Social Media Tools and the Arab Revolts. Alternative Politics 3: 420.

Terrab, Mustafa, Alexandre Serot, and Carlo Rossotto. 2004. Meeting the Competitiveness Challenge in the Middle East and North Africa. Washington, DC: The World Bank Group.

The Emirates Center for Strategic Studies and Research. 2006. Arab Media in the Information Age. Abu Dhabi: The Emirates Center for Strategic Studies and Research.

Tufekci, Zeynep, and Christopher Wilson. 2012. Social media and the decision to participate in political protest: Observations from Tahrir Square. Journal of Communication 62: 363-79. [CrossRef]

UN General Assembly. 1948. Plenary Meetings. Official Records. New York: UN General Assembly, vol. 6. 
Universal Islamic Declaration of Human Rights. 1981. Paris. Available online: http://www.alhewar.com/ ISLAMDECL.html (accessed on 7 November 2018).

Warf, Barney. 2011. Geographies of global Internet censorship. GeoJournal 76: 1-23. [CrossRef]

Warf, Barney, and John Grimes. 1997. Counterhegemonic discourses and the Internet. Geographical Review 87: 259-74. [CrossRef]

World Bank. 2012. World Development Indicators Online; Washington, DC: World Bank. Available online: http: / / data.worldbank.org/indicator/ (accessed on 9 August 2018).

Yemen's Constitution. 1991. San'a. Available online: https://www.constituteproject.org/constitution/Yemen_ 2001.pdf (accessed on 7 November 2018). 